\title{
Exchange Rate Uncertainty and Export Decisions in the UK
}

\author{
David Greenaway \\ University of Nottingham \\ Richard Kneller \\ University of Nottingham \\ Xufei Zhang \\ Middlesex University
}

\begin{abstract}
Using data on UK manufacturing firms, we examine the effects of exchange rate uncertainty on firm decisions on export market entry and export intensity. The use of micro data and new measures of exchange rate uncertainty enable us to test for hysteresis effects in a new way and to test the sensitivity of results to a range of different measures. The results show that exchange rate uncertainty has little effect on firms' export participation but a significant impact on export intensity. We find that industry heterogeneity is important and there would be serious problems of aggregation using pooling and aggregate data.
\end{abstract}

- JEL Classification: D81, F23, F31, F36

- Keywords: Exchange Rate Uncertainty, Export Share, Hysteresis Effects

\footnotetext{
*Corresponding address: Professor David Greenaway; GEP School of Economics, University of Nottingham, UK NG7 2RD, Tel: +44 (0)115 951 3001, Email: david.greenaway@nottingham.ac.uk/Dr Richard Kneller; School of Economics, University of Nottingham, UK NG7 2RD, Tel: +44 (0)115 951 4734, Email: richard.kneller@nottingham.ac.uk/Dr Xufei Zhang; Business School, Middlesex University, UK NW4 4BT, Tel: +44 (0)20 8411 5875, Email: X.Zhang@mdx.ac.uk.

(2010-Center for Economic Integration, Sejong Institution, Sejong University, All Rights Reserved.
} 


\section{Introduction}

Large exchange rate fluctuations since the 1970s have generated interest in investigating the effects of exchange rate movements on international trade. ${ }^{1}$ It was first shown by Baldwin (1988) that when market-entry costs are sunk, large exchange rate fluctuations can induce entry or exit into export markets and also persistence in firms' export market participation. However, despite the clear placement of firms at the heart of models of uncertainty in exchange rates and trade, the majority of empirical evidence remains based on macro data. This remains true even with the recent increase in empirical evidence on the role firms play in exports (Greenaway and Kneller, 2007a).

Although theoretical models show there are hysteresis effects of exchange rate uncertainty on trade price and quantities, and the size of gap between exchange rates that trigger entry and exit is increasing with uncertainty, existing empirical studies using macro data just focus on investigating the simple correlation between trade and measures of exchange rate uncertainty. Though many researchers and policy makers believe that exchange rate uncertainty (volatility) may depress trade, early empirical work (see IMF (1984) and McKenzie (1999) for surveys) did not yield consistent results: there exists little or no significant evidence for a negative effect between exchange rate volatility and trade volume. More recent empirical work (See Clark et al (2004) for a survey) has found some evidence of a negative relationship but it is reported as small in magnitude. Empirical evidence from micro data, however, is limited. The evidence for uncertainty-investment is vast using both aggregate and disaggregated data, which provide some implications for our empirical study.

Of the difficulties with estimating the relationship between exchange rate uncertainty and trade using macro data, two perhaps best highlight the advantages of applying micro data. First, in the aggregate data the test for a simple correlation between the two may be mis-specified if, as theoretical models show, there is hysteresis in the response of trade to exchange rate uncertainty. In macro data the relative scarcity of observations on entry and exit makes it difficult to observe the effects on the extensive margin. Second, the literature often relies on measures that do not take into account the expected component of exchange rates. The opportunity for firms to hedge against exchange rate movements highlights the

${ }^{1}$ In particular, empirical studies of the impact of exchange rate uncertainty on trade flows have become an important area within international finance. 
importance of this. These issues underpin this paper. It aims to examine empirically the effects of exchange rate uncertainty on firm export decisions using firm level micro data for UK manufacturing firms.

In addition to providing the first evidence for UK manufacturing firms we contribute to the literature in two other respects. The first is to account for the hysteresis effects on firm export behaviour by modelling both the extensive and intensive margin of exports. Second, we construct three trade-weighted measures of exchange rate uncertainty at industry level, none of which have been previously applied in a micro setting. As there is no single accepted measure of uncertainty we show that it is important to test the sensitivity of the results to a range of different measures. ${ }^{2}$ The differences in uncertainty across industries also enable us to investigate industry heterogeneity in the effects of uncertainty. This has been largely unexplored in the literature.

The structure of this paper is as follows: to motivate our empirical analysis, we first review the theoretical literature in Section II. Section III explains our method for measuring exchange rate uncertainty. We introduce the firm level data and sample used to estimate the model, and then the methodology and empirical implications from theoretical models are discussed in Section IV. Section V presents the results, and conclusions are set out in Section VI.

\section{Theoretical Background}

The theoretical models describing the effects of exchange rate uncertainty on firm export behaviour can be split into two groups. One strand is the literature on the relationship between exchange rate uncertainty and international trade. The other might be drawn from the literature on investment under uncertainty. It has some of the same characteristics as export behaviour: incurring sunk costs and requiring investment. Thus, we can reasonably regard the firm's entry into export markets as investment under uncertainty.

\section{A. Exchange rate uncertainty and trade}

In the theoretical literature on the impact of exchange rate uncertainty on trade, there is a critical assumption of sunk entry costs that cause hysteresis effects of

${ }^{2}$ In part this results from there being no generally accepted model of firm behaviour subject to risk of exchange rate uncertainty. "Theory cannot provide definitive guidance as to which measure is most suitable" (Clark et al, 2004). 
exchange rate movements on trade prices and quantities. Baldwin (1988) introduced the idea that large exchange rate swings can cause hysteresis effects when market entry costs are sunk. One limitation of Baldwin (1988) is the assumption of perfect foresight, while Baldwin and Krugman (1989) assume that the levels of real exchange rate at successive instants of time are independently and identically distributed. Though this novel theory clearly shows the role of sunk costs in inducing hysteresis effects, the assumption regarding exchange rate forecasting is restrictive.

Dixit (1989a) assumes the real exchange rate is a random walk, or more accurately in continuous time, a Brownian motion. Under this critical assumption, the firm's export market entry and exit decisions can be described as options, and thus the techniques and intuition in of financial economics can be introduced into the model. In this way, the "real option" emerges as a new cause of hysteresis, as greater exchange rate volatility makes entry and exit options more valuable and therefore less readily exercised. The paper shows that the size of the gap between the exchange rates that trigger entry and exit is not constant but an increasing function of uncertainty around current exchange rates. Of course, if there were literally no sunk costs, there could be no hysteresis; but given some sunk costs, the "option" plays a bigger role.

All of the papers in the literature focus on the entry and exit decisions of firms under uncertainty. However, we are also interested in the effects that exchange rate uncertainty has on export intensity decisions. Since empirical work such as Campa (2004) and Bernard and Jensen (2004) shows trade adjustment to exchange rate variability comes mainly from the adjustment of existing exporters, examining the effects on export share seems quite important. However, Dixit (1989b) is the only paper using a similar setup to show that quantity hysteresis can occur when the exchange rate follows a continuous-time random walk. In the case of no sunk entry costs, he assumes a flow fixed costs for production. This assumption is realistic, since if there is no fixed cost, the investment need never be abandoned as it can be kept alive at little loss by choosing very small output. The framework to show quantity hysteresis is just the same as the sunk costs setup in the option approach by substituting fixed costs for sunk costs.

\section{B. Investment under uncertainty}

The literature on investment under uncertainty has grown over the last three decades and is vast. In that literature, Dixit and Pindyck (1994) is a breakthrough. 
Sunk costs, which cause irreversibility, and option theory, are the two key elements, with the prediction of a negative impact of uncertainty on investment due to the option value of delaying investment. The idea is similar to Dixit (1989b): if there are large sunk costs embedded in new capital investment, uncertainty implying an option value of waiting, the firm is more likely to postpone its investment decisions in the face of increased uncertainty until more information becomes available. Uncertainty will depress investment. In particular, an increase in the volatility of the stochastic process that determines the returns from investment will raise the trigger point. Their theoretical framework dominates all the related empirical work, both at macro and micro level of analysis. The extensions of the investment under uncertainty model are various: some consider the type of returns to scale; some take market structure into consideration; the effect on long run equilibrium and short run effect. Different assumptions lead to different arguments of the uncertainty-investment relationship, which provide a broader horizon for empirical work than theoretical models on exchange rate uncertainty and trade.

There are many empirical papers investigating investment under uncertainty. The survey by Carruth et al. (2000) compares the empirical evidence, and shows that studies using aggregate data usually find a significant negative sign, while the overall empirical results from disaggregated data are less conclusive.

Although the theoretical literature does not provide a direct testable proposition to empirically examine hysteresis effects, as it is difficult to compute the thresholds of the investment/export entry decision and examine the relationship between the thresholds and uncertainty, the papers give us a rough picture. These models need to be developed further to draw out empirically testable implications. However, in practice, most studies focus on investigating simple correlations of trade volume / export entry with exchange rate volatility, and rate of investment / uncertainty. As Dixit and Pindyck (1994, p. 421) argue, the theoretical models cannot be directly tested by investigating simple equilibrium relationships between rates of investment and measures of uncertainty. Investigating simple correlations is "a strategy which is highly questionable since any observed significant relationship may be an artefact of underlying model misspecification."

Moreover, Caballero (1991), Dixit and Pindyck (1994), and Darby et al. (1999) have shown that in certain circumstances uncertainty may still have a positive effect. Darby et al. (1999) extend Dixit-Pindyck and show how the impact of exchange-rate uncertainty may vary according to the characteristics of the 
industrial sector. For some industries uncertainty will depress investment, but for others it would foster it. Industry heterogeneity is a determinant of the effect of uncertainty on investment. The literature shows that the overall impact depends on the relative strength of several critical factors such as industrial structure (i.e. the degree of competition), the type of returns to scale, degree of risk aversion, and source of uncertainty itself. The literature thus suggests a problem of aggregation when empirically examining the issue using macro data.

Theoretical work suggests industry heterogeneity is a determinant of investment. Little empirical work investigates this however. Henley, Carruth and Dickerson (2003) show that firm-specific uncertainty and industry-wide uncertainty have opposite effects. We will split our sample by industry to examine this. We should note that although the theory of investment under uncertainty can help explain the export market entry decision of firms under exchange rate uncertainty, it provides little guidance on export behaviour of firms after entry.

\section{Measures of Uncertainty}

It is worth noting that in the literature there is no accepted best way to capture uncertainty: each measure may have some limitations, and since uncertainty is unobservable, we can only employ proxies. For a survey of the measures of uncertainty see Carruth et al. (2000). However, some empirical studies such as Carruth et al. (2000) and Darby et al. (1999) also show that different specifications of uncertainty make little difference to numerical results.

As summarized in Clark et al (2004), the standard deviation of the first difference of the logarithmic spot exchange rate is the most widely used measure in the trade-exchange rate volatility literature. While this has the advantage of being relatively easy to construct it is not without criticism, where these largely centre on the conditions under which volatility and uncertainty are captured by the same measure. The extent to which exchange rate volatility is a source of uncertainty depends on the degree to which exchange rate movements are predictable. This suggests the appropriate measure should be related to deviations between actual and predicted exchange rates. The methodology adopted by many, such as Campa (2004), has been to focus on the canonical conditional variances from ARCH/ GARCH models to predict exchange rates and calculate uncertainty accordingly. Such measures are likely to differ markedly from the actual forecasting behaviour of firms, who are unlikely to have available financial instruments to hedge. 
In the standard theory of Brownian motion in the option approach, uncertainty is modelled as the standard deviation/variance. This measure is also consistent with the theoretical model (see Dixit and Pindyck, 1994). This may be the reason why most papers use this measure. Some earlier papers, such as Bélanger et al. (1992) and Dell'Ariccia (1999), consider the difference between the previous period's forward rate and current spot to be an indicator of exchange rate uncertainty. The percentage difference between the maximum and minimum of the nominal spot rate over a certain period preceding the observation plus a measure of exchange rate misalignment is another measure. This index is more likely to capture medium-run uncertainty, since past large changes may generate expected volatility. As stated in Dell'Ariccia (1999), we should note that the measures of uncertainty mentioned above are backward-looking, as past volatility is used to predict present risk. There are some other issues that also need to be considered: data frequency, which temporal window and so on.

One of the advantages of measures based on differences between the actual and forward exchange rate, as showed in Dell'Ariccia (1999) is that,

under a target zones regime, or under pegged but adjustable exchange rates, it would pick up the effect of the presence of a 'peso problem' or lack of credibility of the official parity.

The measures also take firms' hedge behaviour into consideration. When hedging instruments are available, the predicted part of exchange rate volatility can be hedged away and hence may not have much effect on trade. The extent to which exchange rate volatility is a source of uncertainty depends on the degree to which exchange rate movements are predictable. This suggests that the appropriate measure should be related to deviations between actual and predicted exchange rates. As the rational expectations literature has stressed, only the unexpected portion of a variable really matters and the forecast error used in this paper exploits this idea. Moreover, the measures provide us with a novel way to investigate the issue: all other measures of uncertainty are bounded non-negative, whereas we can embed the direction (positive and negative), as well as the size or magnitude, of uncertainty in this type of measure, which enables us to obtain more informative results. Of course, by using the forward error, we have automatically restricted our analysis to a nominal environment since there is no readily available forward or future market for the real exchange rate. A nominal analysis could well be justified, 
in a quarterly context, by assuming firms are maximizing short-run nominal profits and, consequently, that they are facing only nominal exchange rate uncertainty. We feel, in that context, our measure is appropriate whether traders maximize real or nominal expected profits.

We measure uncertainty based on the trade-weighted difference between the current spot rate and previous period's forward rate. Early examples using the forecast error include Bélanger et al. (1992) and Dell'Ariccia (1999). But their measures are not standard deviations, nor trade-weighted. This measure assumes that firms attempt to forecast and can reduce the uncertainty faced accordingly.

$$
s_{t}=f_{t-1}+\varepsilon_{t}
$$

where $f_{t-1}$ is the forward rates in the period of $t-1, s_{t}$ is the spot exchange rates in time $t$, and $\varepsilon_{t}$ is the forecast error/residual.

Our first measure is calculated as the standard deviation of the residuals of the forecasting model in futures markets. It therefore bears a strong relationship with the more usual standard deviation of spot exchange rates, and indeed we find its correlation with this is 0.91 . The final two measures are based on the forecast errors themselves $\left(\varepsilon_{t}=s_{t}-f_{t-1}\right)$. The first is the absolute value of the forecast error, while the second includes the direction of the error. The use of the difference between current spot and the previous forward rates assumes that hedging is available to each exporter to cover all international transactions and is costless.

Important in the construction of these trade-weighted uncertainty measures are data for spot and forward rates for currencies of the UK's main export destinations by industry. Here we draw on information in Greenaway, Kneller and Zhang (2007), who show that changes in 3-digit industry level real effective exchange rates (REER) rely principally on the Euro (German Mark) and US dollar exchange rates. We use exchange rate data (spot and forward) for these (Euro/GBP and USD/ GBP) and compute the weighted average industry specific exchange rate uncertainty by using normalized export weights for the two currency areas in each 3-digit industry. ${ }^{3}$ The exchange rate data is from Datastream. Since the period between placing an order (signing a contract) and receiving payment is typically three months, we follow Bélanger et al. (1992) and Dell'Ariccia (1999) in choosing the 3 month forward rate. The data is monthly (spot and 3 month forward rates)

\footnotetext{
${ }^{3}$ We include China, Hong Kong, Taiwan, Singapore and Canada into the US dollar area as the currencies in these areas were pegged the US dollar for most of the period we investigate.
} 
measured at mid-month, expressed as foreign currency per GBP. Uncertainty in each time period is then calculated as follows:

(i) the standard deviation of the 12 monthly differences between logarithms of spot rate and 3 month forward rate predicted 3 months earlier (positive if appreciation, negative if depreciation): $\mathrm{SD}\left(\varepsilon_{t}\right)$ (FSSD, hereafter);

(ii) the average of the 12 monthly differences between logarithms of spot rate and 3 month forward rate predicted 3 months earlier: $\left(\sum \varepsilon_{t}\right) / 12$ (AVG, hereafter); a positive value implies an unexpected appreciation in uncertainty, a negative value unexpected depreciation.

(iii) the average of the absolute value of the 12 monthly differences: $\left(\sum\left|\varepsilon_{t}\right|\right) / 12$ (ABS, hereafter).

To capture short run uncertainty, we lag each 3 months, i.e. for each year the 12 monthly data is from October of the previous year to September of the current year. The average of differences (AVG), which can be negative or positive, captures the direction of exchange rate uncertainty; whereas the standard deviation (FSSD) and the average of absolute differences (ABS) are two proxies for the size or magnitude of the uncertainty.

Table 1 shows correlations between the three measures. The FSSD measure is strongly correlated with ABS, with a correlation of 0.75 . AVG in contrast would appear to behave very differently, and the correlation with FSSD is negative. All correlations are small in size. Using the direction of the forecast error clearly captures a different aspect of uncertainty.

In Figure 1 we present the uncertainty measures across time for 8 representative industries. The measures of uncertainty follow a roughly similar pattern across industries with small variations in magnitude. The most volatile measure is AVG: fluctuating between -0.03 to 0.025 ; the measures of ABS and FSSD move between 0.01-0.04.

One feature of the data is worthy of note and has a significant bearing on the empirical evidence presented below. There is a large change for the UK for 1993

Table 1. Correlation Matrix for Uncertainty Measures

\begin{tabular}{cccc}
\hline & FSSD & ABS & AVG \\
\hline FSSD & 1.000 & & \\
ABS & 0.748 & 1.000 & \\
AVG & -0.445 & 0.127 & 1.000 \\
\hline
\end{tabular}


Figure 1. 3-digit Industry Specific Exchange Rate Uncertainty
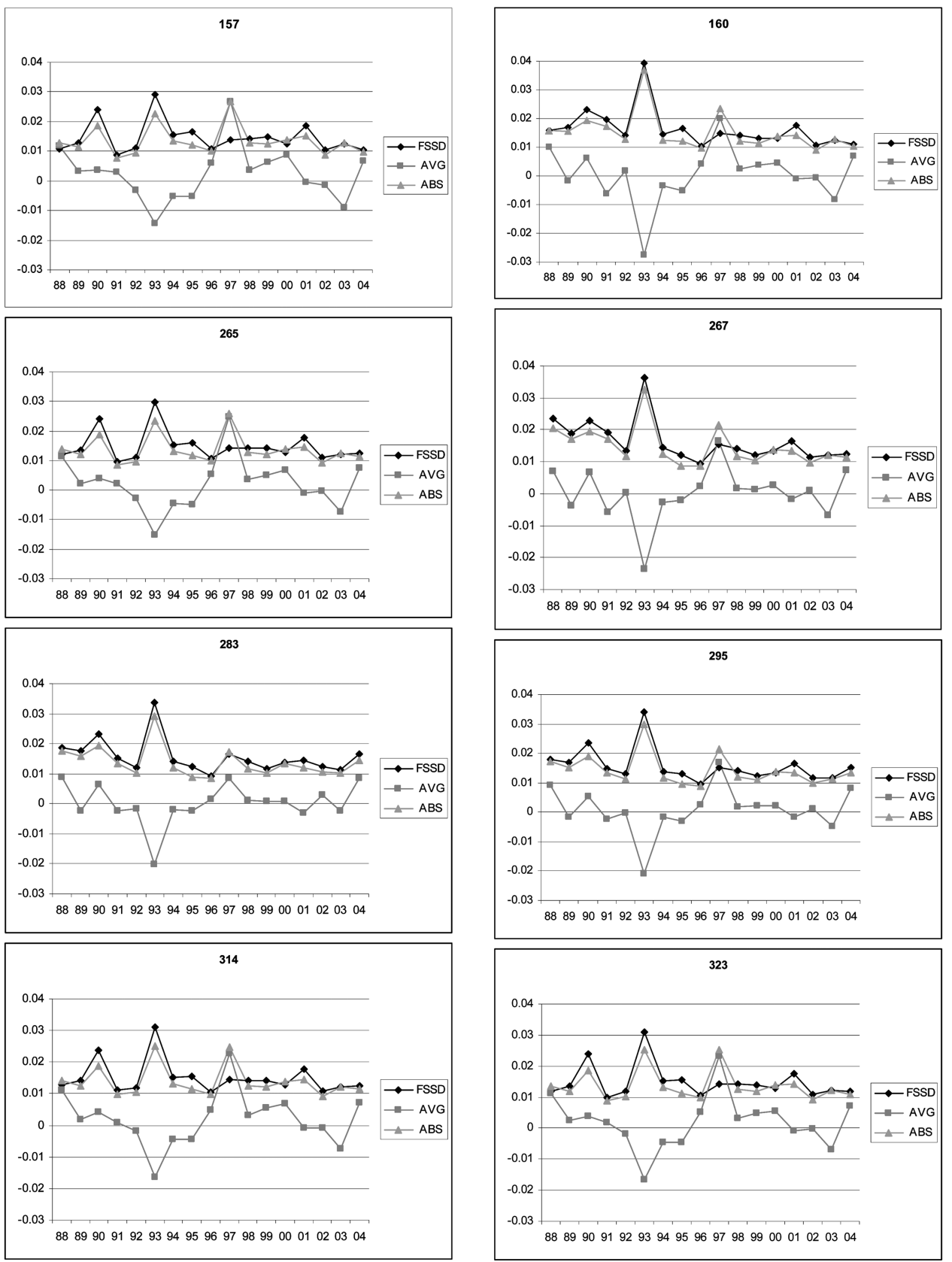

Note:

FSSD: the standard deviation of the 12 monthly differences between spot rate and forward rate. AVG: the average of the 12 monthly differences between spot rate and forward rate.

ABS: the average of the 12 monthly absolute value of differences between spot rate and forward rate. 
under all of the measures. This coincides with the UK's withdrawal from the European Exchange Rate Mechanism (ERM), known colloquially as "Black Wednesday" (16 September 1992). ${ }^{4}$ The data show that in the period leading up to this the forward rate expectation was that sterling would remain within the allowed fluctuation bands of $+/-6 \%$. The devaluation of sterling meant that the spot rate in period $t$ was therefore very different from the expectation in period $\mathrm{t}-1$, when export contracts were written. This is captured as an unexpected depreciation of sterling under the AVG measure and an increase in volatility under the FSSD and ABS measures.

\section{Firm Data and Methodology}

\section{A. Firm data}

Our firm level panel dataset is constructed from the Bureau Van Dijk database Financial Analysis Made Easy (FAME) database and from OneSource, used by amongst others, Girma et al. (2004) and Greenaway and Kneller (2007b). It includes a majority of large UK manufacturing firms. ${ }^{5}$ As only larger firms are required to report information about whether they export or not, dropping firms with incomplete information on their export behaviour may be likely to create sample selection bias. The data cover the 17 year period from 1988 to 2004. After removing firms with missing values we are left with a sample of 44, 252 observations on 5,876 companies. It has an unbalanced structure, with an average of 8 observations per firm. ${ }^{6}$

\section{B. Methodology and empirical implications}

We adopt a two-stage sample selection model. Our econometric analysis accounts for both decisions and the fact that they are interdependent. ${ }^{7}$ Two

\footnotetext{
${ }^{4}$ As our annual uncertainty measures are calculated using 3-month lagged monthly data, annual measures for 1993 are computed by monthly data from October 1992 to September 1993. The effects of the ejection from the ERM thus appear in the data in 1993.

${ }^{5}$ In principle, in the UK, all limited companies have to prepare accounts and file them with the Registrar of Companies. However, there are a number of exemptions. Small companies are not required to submit detailed information. Small and medium firms are not required to report their export turnover, whereas larger firms are required to report it only if it is significant.

${ }^{6}$ See Greenaway, Kneller and Zhang (2007) for summary statistics of characteristics of UK manufacturing firms.

${ }^{7}$ Kneller and Pisu (2005) and Karpaty and Kneller (2005) adopt the same methodology.
} 
equations are estimated,

$$
\begin{gathered}
y^{*}{ }_{i t}=x_{i, t-1} \beta+u_{i t}(\text { outcome equation: export intensity/export share); } \\
d^{*}{ }_{i t}=z_{i, t-1} \gamma+v_{i t} \text { (selection equation: export participation); }
\end{gathered}
$$

with

$$
y_{\text {it }}=y^{*}{ }_{\text {it }} \text { if } d_{\text {it }}=1 \quad y_{\text {it }}=0 \text { if } d_{i t}=0
$$

and

$$
d_{i t}=1 \text { if } d^{*}{ }_{i t}>0 \quad d_{i t}=0 \text { if } d^{*}{ }_{i t} \leq 0
$$

Thus, the observed $y_{i t}$, which is the export share, is zero when the firm decides not to export $\left(d_{i t}=0\right)$ and positive when it exports $\left(d_{i t}=1\right)$. The distribution of the error terms $\left(u_{i t}, v_{i t}\right)$ is assumed to be bivariate normal with correlation $\rho$. The two equations are related if $\rho \neq 0$. In this case estimating only the export share regression would induce sample selection bias in the estimate of $\beta$ due to the error term $u_{i t}$, and the regressor $x$ would be correlated. To avoid this problem both equations must be estimated via maximum likelihood or a two-step method proposed by Heckman (1979). We employed the former as it is more efficient. ${ }^{8}$

The independent variables used in the selection equation are as follows: Uncertainty $_{i t}$ : the 3-digit industry-specific exchange rate uncertainty; inREER ${ }_{i t}$ : the 3-digit industry-specific REER as in Greenaway, Kneller and Zhang (2007); $\mathrm{emp}_{i t}$ : the log number of employees; Wage $_{i t}$ : the average wage; laborprod $_{i t}$ : labour productivity; foreign $n_{i}$ : a dummy equal to 1 if the firm is foreign owned, and 0 otherwise; $\exp _{i t}$ : a dummy variable equals to 1 if firm $i$ exported in year $\mathrm{t}$, and 0 otherwise.

We should acknowledge some potential limitations of the Heckman selection model. The most typical concern when using panel data sample selection models has been the presence of unobserved heterogeneity. Heterogeneity across firms and industries may arise for example as a result of different characteristics. These individual characteristics may be unobservable, or may not be measurable. Failure to account for such unobserved heterogeneity may result in biased and inconsistent estimates of the parameters of interest. Vella and Verbeek (1999) and Kyriazidou (1997) introduce several methods to deal with this. Many papers assume strict exogeneity of the independent variables in two equations. Vella and Verbeek

${ }^{8}$ See Greene (2003) for the discussion. 
(1999) propose a procedure dealing with binary and censored endogenous variables. It seems attractive to our estimation, as it also allows for inclusion of the lagged dependent variable in the selection equation. However, existing methods for panel sample selection models are generally in a static framework. Recent papers such as Kyriazidou (2001) allow for dynamics in both the selection equation and outcome equation.

Our estimation of the sample selection model with panel data is quite straightforward in a static framework: the maximum likelihood estimation of pooled Heckman selection model with lagged dependant variable, i.e. the lagged export dummy, in the selection equation, together with time and industry dummies in both equations to control for any fixed effects. This is generally a cross-section data analysis. We are unable to deal with possible unobserved heterogeneity and full dynamics due to computational demands and absence of appropriate software. Using lagged independent variables in the sample selection model is the simple way we deal with possible endogeneity.

According to the theory, if the persistent band for a firm to invest (the investment threshold) increases with the magnitude of uncertainty, we may expect an insignificant relationship between the magnitude of uncertainty and export entry, instead of a negative or positive effect. As the standard measures of uncertainty are bounded non-negative, we may regard those measures as proxies for the magnitude of uncertainty. So using the non-negative measures ABS and FSSD, there should be no significant relationship between each and firms export decisions. If, however, we can separate the different monthly directions (positive and negative) of uncertainty within a period (a year), and the uncertainties for different directions are asymmetric (the magnitude of uncertainty in one direction is averagely larger than that in the other during the period), we may observe a significant effect of net uncertainty beyond a symmetric band on investment. In the case of exchange rate uncertainty, a net depreciation/appreciation over the predicted forward rate in uncertainty will induce entry into/exit from export markets. So using the proxy for the average direction of exchange rate uncertainty AVG, we may find some significant effects.

As most empirical papers using micro data do not observe the effects of exchange rate volatility on entry into export markets, which may be due to large sunk entry costs (thus high thresholds) and rarity of observations of entry, we may not observe the effects on export market entry. However, we may observe quantity hysteresis within exporters. As pointed out in Dixit (1989b), in the case of no sunk 
Table 2. Heckman Selection Model (MLE): Uncertainty

\begin{tabular}{|c|c|c|c|c|c|c|}
\hline \multirow[b]{3}{*}{$\begin{array}{l}\text { Lag Ex } \\
\text { dum }\end{array}$} & \multicolumn{2}{|c|}{ (1) Uncertainty: FSSD } & \multicolumn{2}{|c|}{ (2) Uncertainty: AVG } & \multicolumn{2}{|c|}{ (3) Uncertainty: ABS } \\
\hline & $\begin{array}{l}\text { Export } \\
\text { Dummy }\end{array}$ & $\begin{array}{l}\text { Export } \\
\text { Share }\end{array}$ & $\begin{array}{l}\text { Export } \\
\text { Dummy }\end{array}$ & $\begin{array}{l}\text { Export } \\
\text { Share }\end{array}$ & $\begin{array}{c}\text { Export } \\
\text { Dummy }\end{array}$ & $\begin{array}{l}\text { Export } \\
\text { Share }\end{array}$ \\
\hline & $\begin{array}{c}3.04 \\
(39.99)^{* * *}\end{array}$ & & $\begin{array}{c}3.04 \\
(39.94)^{* * *}\end{array}$ & & $\begin{array}{c}3.04 \\
(39.95)^{* * *}\end{array}$ & \\
\hline $\begin{array}{c}\text { LagIndustry } \\
\text { REER }\end{array}$ & $\begin{array}{r}0.002 \\
(0.32)\end{array}$ & $\begin{array}{c}-0.004 \\
(-2.03)^{* *}\end{array}$ & $\begin{array}{l}0.00201 \\
(0.32)\end{array}$ & $\begin{array}{l}-0.0037 \\
(-1.98)^{* *}\end{array}$ & $\begin{array}{l}0.00215 \\
(0.34)\end{array}$ & $\begin{array}{l}-0.00393 \\
(-2.02)^{* *}\end{array}$ \\
\hline $\begin{array}{c}\text { Lag log of } \\
\text { employment }\end{array}$ & $\begin{array}{r}0.0435 \\
(2.31)^{* *}\end{array}$ & $\begin{array}{l}0.0021 \\
(0.47)\end{array}$ & $\begin{array}{c}0.0435 \\
(2.31)^{* *}\end{array}$ & $\begin{array}{l}0.00212 \\
(0.45)\end{array}$ & $\begin{array}{c}0.0435 \\
(2.31)^{* *}\end{array}$ & $\begin{array}{l}0.00206 \\
(0.44)\end{array}$ \\
\hline $\begin{array}{l}\text { Lag log of } \\
\text { wage }\end{array}$ & $\begin{array}{r}0.036 \\
(0.74)\end{array}$ & $\begin{array}{c}0.0914 \\
(3.08)^{* * *}\end{array}$ & $\begin{array}{l}0.0366 \\
(0.74)\end{array}$ & $\begin{array}{l}0.091 \\
(3.07)^{* * *}\end{array}$ & $\begin{array}{l}0.0363 \\
(0.73)\end{array}$ & $\begin{array}{c}0.0915 \\
(3.09)^{* * *}\end{array}$ \\
\hline $\begin{array}{l}\text { Lag log of } \\
\text { labor prod. }\end{array}$ & $\begin{array}{l}0.0374 \\
(1.19)\end{array}$ & $\begin{array}{c}-0.01 \\
(-1.08)\end{array}$ & $\begin{array}{l}0.0374 \\
(1.19)\end{array}$ & $\begin{array}{r}-0.010 \\
(-1.07)\end{array}$ & $\begin{array}{l}0.0374 \\
(1.19)\end{array}$ & $\begin{array}{l}-0.0101 \\
(-1.09)\end{array}$ \\
\hline $\begin{array}{l}\text { Lag log of } \\
\text { age }\end{array}$ & $\begin{array}{l}-0.0244 \\
(-1.56)\end{array}$ & $\begin{array}{l}-0.0097 \\
(-2.55)^{* *}\end{array}$ & $\begin{array}{l}-0.0244 \\
(-1.56)\end{array}$ & $\begin{array}{l}-0.0097 \\
(-2.53)^{* *}\end{array}$ & $\begin{array}{l}-0.0244 \\
(-1.56)\end{array}$ & $\begin{array}{l}-0.0096 \\
(-2.53)^{* *}\end{array}$ \\
\hline $\begin{array}{l}\text { Foreign } \\
\text { dummy }\end{array}$ & $\begin{array}{l}0.132 \\
(4.27)^{* * *}\end{array}$ & $\begin{array}{l}0.058 \\
(6.80)^{* * *}\end{array}$ & $\begin{array}{c}0.1316 \\
(4.26)^{* * *}\end{array}$ & $\begin{array}{l}0.058 \\
(6.81)^{* * *}\end{array}$ & $\begin{array}{c}0.1318 \\
(4.26)^{* * *}\end{array}$ & $\begin{array}{l}0.058 \\
(6.80)^{* * *}\end{array}$ \\
\hline $\begin{array}{c}\text { Uncertainty } \\
\text { (FSSD) }\end{array}$ & $\begin{array}{c}2.30 \\
(0.15)\end{array}$ & $\begin{array}{l}4.486 \\
(1.83)^{*}\end{array}$ & & & & \\
\hline $\begin{array}{c}\text { Uncertainty } \\
\text { (AVG) }\end{array}$ & & & $\begin{array}{l}3.23 \\
(0.34)\end{array}$ & $\begin{array}{l}-5.144 \\
(-2.18)^{* *}\end{array}$ & & \\
\hline $\begin{array}{c}\text { Uncertainty } \\
\text { (ABS) }\end{array}$ & & & & & $\begin{array}{c}-0.42 \\
(-0.03)\end{array}$ & $\begin{array}{l}-0.623 \\
(-0.27)\end{array}$ \\
\hline \multicolumn{7}{|l|}{$\begin{array}{c}\text { Uncertainty } \\
\text { (SD) }\end{array}$} \\
\hline $\begin{array}{l}\text { Lambda } \\
\text { (std. error) }\end{array}$ & \multicolumn{2}{|c|}{$-0.034(0.006)^{* * *}$} & \multicolumn{2}{|c|}{$-0.0339(0.006)^{* * *}$} & \multicolumn{2}{|c|}{$-0.034(0.006)^{* * *}$} \\
\hline $\begin{array}{c}\text { Rho } \\
\text { (std. error) }\end{array}$ & \multicolumn{2}{|c|}{$-0.1327(0.021)^{* * *}$} & \multicolumn{2}{|c|}{$-0.1323(0.021)^{* * *}$} & \multicolumn{2}{|c|}{$-0.1331(0.021)^{* * *}$} \\
\hline
\end{tabular}

Observations: 44, 251 Firms: 5, 876

Notes: (i) $\mathrm{Z}$ statistics in parentheses, robust standard errors adjusted for 83 clusters in 3-digit industries. (ii) *significant at $10 \%$; * significant at $5 \%$; *** significant at $1 \%$

(iii) $\rho$ is the estimated correlation between the error terms of the two equations; if it is different from zero it suggests that the two equations are related and that the selection model is appropriate; $\lambda$ is the estimated coefficients of the inverse Mills ratio; if it is different from zero it suggests that there is sample selection. 
Table 3. Models of Export Participation

\begin{tabular}{ccc}
\hline $\begin{array}{c}\text { Uncertainty } \\
\text { measure }\end{array}$ & $\begin{array}{c}\text { (1)Fixed-effects Linear probability } \\
(\mathrm{t} \text { statistic) }\end{array}$ & $\begin{array}{c}\text { (2)Ramdom-effects } \\
\text { Probit (z statistic) }\end{array}$ \\
\hline AVG & $0.5325(0.63)$ & $3.643(0.30)$ \\
ABS & $1.236(1.03)$ & $3.68 \quad(0.43)$ \\
\hline
\end{tabular}

* indicates significant at $10 \%$; * indicates significant at $5 \%$; ** indicates significant at $1 \%$.

entry cost, there is a fixed costs for production, and fixed costs play the same role of sunk costs in hysteresis. As the fixed costs are much less than the sunk costs, we are more likely to observe hysteresis.

\section{Results}

The results of the baseline sample selection model are shown in Table 2. These suggest differences between the effects of uncertainty on the intensive and extensive margins and between different measures of uncertainty. In no case do we find a correlation between uncertainty and the extensive margin, but a significant correlation for two of the three measures for the intensive margin. The exception is the absolute forecast error (ABS) in Column 3. The two significant measures of uncertainty have differently signed effects on the intensive margin however. In Column 1 greater uncertainty positively affects the export intensity of firms; whereas in Column 2 greater uncertainty leads to lower trade.

To check robustness, we use another estimation methodology. Table 3 reports the results using a fixed-effects linear probability model and a random-effects probit model for firms export entry. The coefficients for uncertainty (measured as ABS and AVG) are insignificant in both, which suggests little effect of exchange rate uncertainty on firm export entry decision. ${ }^{9}$ The results are consistent with the results of the export entry equation in Table 2 . We also include the means of timevarying firm characteristics in the baseline Heckman-selection regression to control for firm fixed effects, and the results for exchange rate uncertainty remain unchanged.

While in some models uncertainty is predicted to have a positive relationship with exports, this is unexpected. As indicated above the correlation for this measure relies on the behaviour of uncertainty measures in 1993. To check the

${ }^{9}$ The results using the measure of FSSD are similar to those using ABS. We do not report the results for brevity. 
Table 4. Heckman Selection Model (MLE): Robustness

\begin{tabular}{|c|c|c|c|c|}
\hline & \multicolumn{2}{|c|}{$\begin{array}{c}\text { (1) Uncertainty: FSSD } \\
\text { without } 1993\end{array}$} & \multicolumn{2}{|c|}{$\begin{array}{l}\text { (2) Uncertainty: AVG } \\
\text { without } 1993\end{array}$} \\
\hline & Export Dummy & Export Share & Export Dummy & Export Share \\
\hline Lag Export dummy & $\begin{array}{c}3.04 \\
(40.12)^{* * *}\end{array}$ & & $\begin{array}{c}3.04 \\
(40.07)^{* * *}\end{array}$ & \\
\hline LagIndustry REER & $\begin{array}{r}0.003 \\
(0.45)\end{array}$ & $\begin{array}{l}-0.0042 \\
(-2.07)^{* *}\end{array}$ & $\begin{array}{l}0.0028 \\
(0.41)\end{array}$ & $\begin{array}{l}-0.004 \\
(-2.04)^{* *}\end{array}$ \\
\hline $\begin{array}{l}\text { Lag log of } \\
\text { employment }\end{array}$ & $\begin{array}{r}0.0429 \\
(2.20)^{* *}\end{array}$ & $\begin{array}{l}0.0028 \\
(0.59)\end{array}$ & $\begin{array}{l}0.04295 \\
(2.20)^{* *}\end{array}$ & $\begin{array}{l}0.0028 \\
(0.59)\end{array}$ \\
\hline Lag log of wage & $\begin{array}{l}0.0425 \\
(0.88)\end{array}$ & $\begin{array}{l}0.097 \\
(3.72)^{* * *}\end{array}$ & $\begin{array}{l}0.0427 \\
(0.88)\end{array}$ & $\begin{array}{l}0.097 \\
(3.71)^{* * *}\end{array}$ \\
\hline $\begin{array}{l}\text { Lag } \log \text { of } \\
\text { labor prod. }\end{array}$ & $\begin{array}{r}0.033 \\
(1.05)\end{array}$ & $\begin{array}{l}-0.011 \\
(-1.13)\end{array}$ & $\begin{array}{r}0.033 \\
(1.06)\end{array}$ & $\begin{array}{l}-0.011 \\
(-1.13)\end{array}$ \\
\hline Lag log of age & $\begin{array}{l}-0.0253 \\
(-1.60)\end{array}$ & $\begin{array}{l}-0.0104 \\
(-2.80)^{* * *}\end{array}$ & $\begin{array}{l}-0.0254 \\
(-1.61)\end{array}$ & $\begin{array}{l}-0.0104 \\
(-2.79)^{* * *}\end{array}$ \\
\hline Foreign dummy & $\begin{array}{l}0.139 \\
(4.26)^{* * *}\end{array}$ & $\begin{array}{l}0.058 \\
(6.87)^{* * *}\end{array}$ & $\begin{array}{l}0.139 \\
(4.26)^{* * *}\end{array}$ & $\begin{array}{l}0.058 \\
(6.88)^{* * *}\end{array}$ \\
\hline Uncertainty (FSSD) & $\begin{array}{c}-3.01 \\
(-0.18)\end{array}$ & $\begin{array}{c}3.34 \\
(1.46)\end{array}$ & & \\
\hline Uncertainty (AVG) & & & $\begin{array}{c}6.56 \\
(0.66)\end{array}$ & $\begin{array}{l}-4.43 \\
(-2.01)^{* *}\end{array}$ \\
\hline Lambda (std. error) & \multicolumn{2}{|c|}{$-0.0335(0.006)^{* * *}$} & \multicolumn{2}{|c|}{$-0.033(0.006)^{* * *}$} \\
\hline Rho (std. error) & \multicolumn{2}{|c|}{$-0.1305(0.022)^{* * *}$} & \multicolumn{2}{|c|}{$-0.1300(0.022)^{* * *}$} \\
\hline
\end{tabular}

Notes: See notes for Table 2.

sensitivity of our results to the events of the UK's exit from the ERM we drop the observations in 1993 and repeat the analysis. The results are shown in Table 4. In column 1 we now find the effects of FSSD become insignificant in both the export entry and export intensity equations. In contrast, the coefficient for AVG in Column 2 is still negative and significant. ${ }^{10}$ According to our results, whether or not the uncertainty changes greatly in magnitude, it has little impact on the export behaviour of firms. What matters is the direction of the asymmetric uncertainty movements.

\footnotetext{
${ }^{10}$ The results using the conventional standard deviation of first differences of the logarithmic spot exchange rates (SD) as the measure and dropping observations for 1993 show that the coefficient for $\mathrm{SD}$ in export intensity equation is still positive and strongly significant as before.
} 
To investigate industry heterogeneity, we split our sample by 2-digit industries and run the baseline regression for each industry. The coefficients of exchange rate uncertainty are different from the evidence using the pooled sample, as there are significant effects for some industries using ABS and FSSD. And we also observe some positive effects for some industries. However, different measures tell different stories for the same industry. The coefficients are unstable and hard to analyze systematically. However, the results strongly suggest industry heterogeneity and further investigation of industry characteristics is required to fully understand this.

We focus on the results using AVG as the measure. 5 out of 16 industries have a significant coefficient both for the export participation decision and export share decision, which suggests a significant effect of uncertainty on exports. Table 5

Table 5. Summary of Industry Heterogeneity (AVG as proxy for uncertainty)

\begin{tabular}{|c|c|}
\hline Different effect type & Industries \\
\hline $\begin{array}{l}\text { export entry } \\
\text { (negative), } \\
\text { export share } \\
\text { (insignificant } \\
\text { or negative) }\end{array}$ & $\begin{array}{l}20 \text { Manufacture of Wood And Products of Wood And Cork, Except } \\
\text { Furniture; Manufacture of Articles of Straw and Plaiting Materi- } \\
\text { als } \\
26 \text { Manufacture of Other Non-metallic Mineral Products } \\
27 \text { Manufacture of Basic Metals }\end{array}$ \\
\hline $\begin{array}{l}\text { export entry } \\
\text { (insignificant) } \\
\text { export share } \\
\text { (negative) }\end{array}$ & $\begin{array}{l}15 \text { Manufacture of Food Products and Beverages } \\
22 \text { Publishing, Printing and Reproduction of Recorded Media } \\
28 \text { Manufacture of Fabricated Metal Products, Except Machinery } \\
\text { and Equipment } \\
31 \text { Manufacture of Electrical Machinery and Apparatus Not } \\
\text { Elsewhere Classified }\end{array}$ \\
\hline $\begin{array}{l}\text { Insignificant in } \\
\text { both decisions }\end{array}$ & $\begin{array}{l}17 \text { Manufacture of Textiles } \\
29 \text { Manufacture of Machinery and Equipment Not Elsewhere } \\
\text { Classified } \\
34 \text { Manufacture of Motor Vehicles, Trailers and Semi-trailers }\end{array}$ \\
\hline $\begin{array}{l}\text { export entry } \\
\text { (positive) } \\
\text { export share } \\
\text { (insignificant } \\
\text { or positive) }\end{array}$ & $\begin{array}{l}24 \text { Manufacture of Chemicals and Chemical Products } \\
32 \text { Manufacture of Radio, Television and Communication Equip- } \\
\text { ment and Apparatus } \\
36 \text { Manufacture of Furniture; Manufacturing Not Elsewhere } \\
\text { Classified }\end{array}$ \\
\hline $\begin{array}{l}\text { export entry (positive) } \\
\text { export share (negative) }\end{array}$ & 18 Manufacture of Wearing Apparel; Dressing and Dyeing of Fur \\
\hline $\begin{array}{l}\text { export entry (negative), } \\
\text { export share (positive) }\end{array}$ & $\begin{array}{l}33 \text { Manufacture of Medical, Precision and Optical Instruments, } \\
\text { Watches and Clocks } \\
35 \text { Manufacture of Other Transport Equipment }\end{array}$ \\
\hline
\end{tabular}


reports the summary of the effects across 2-digit industries with detailed industry information, which splits industries into 6 categories according to different effects on entry and intensity. We list negative effect categories at the top, insignificant effects in the middle, and positive effects and opposite effects (between export entry and export intensity) categories at the bottom. It is interesting to see that, in general, the industries with low levels of skills and technology incur negative effects on export decisions, whereas industries with high technology incur insignificant or positive effects. The results are consistent with the hypothesis of Darby et al. (1999) considering different characteristics across industries. However, there are three industries with contradictory effects for export entry and export share decisions. There may be a combination of several roles that makes the results not so straightforward.

\section{Conclusions}

In this paper we investigate the responsiveness of exports of UK firms to different measures of exchange rate uncertainty. We find conclusively that they have no effect on the decision to participate in export markets using a pooled sample. Of the effect on the intensive margin of firm exports there is an unexpected positive relationship for measures that do not control for the direction of the forecast error. This correlation is driven by the use of a single year of data. Once controlled for we find that only the direction of uncertainty, whether an appreciation or depreciation was expected is important for exports. Our results provide an indirect way to test the hysteresis hypothesis. We also find that industry heterogeneity is important and there would be serious problems of aggregation using pooling and aggregate data. Future research should investigate the characteristics of industries and their impacts on the role of uncertainty.

\section{Acknowledgements}

The authors gratefully acknowledge comments from an anonymous Referee and helpful advice from the Editor, as well as financial support from the Leverhulme Trust under Programme Grant F/00 114/AM.

Received 17 February 2010, Revised 26 July 2010, Accepted 6 August 2010 


\section{References}

Baldwin, Richard. (1988), Hysteresis and the Beachhead Effect, American Economic Review, 78, pp. 773-85.

Baldwin, R. and Krugman, P. (1989), Persistent Trade Effects of Large Exchange Rate Shocks, Quarterly Journal of Economics, 104, pp. 635-54.

Bélanger, Denis, Sylvia Gutiérrez, Daniel Racette and Jacques Raynauld (1992),

Bernard, A. and Jensen, J. (2004b), Entry, Expansion and Intensity in the U.S. Export Boom, 1987-1992, Review of International Economics, 12, pp. 662-675.

Caballero, R. J. (1991), On the Sign of the Investment-Uncertainty Relationship, The American Economic Review, 81(1), pp. 279-288.

Campa, J. M. (2004), Exchange Rates and Trade: How Important is Hysteresis in Trade?, European Economic Review, 48, pp. 527-548.

Carruth, A., A. Dickerson and A. Henley (2000a), What Do We Know about Investment under Uncertainty?, Journal of Economic Surveys, 14(2), pp. 119-153.

Clark et al (2004), A New Look at Exchange Rate Volatility and Trade Flows, IMF Occasional Paper 235.

Darby, J., A. Hughes-Hallett, J. Ireland and L. Piscitelli (1999), The Impact of Exchange Rate Uncertainty on the Level of Investment, The Economic Journal, 109, C55-C67.

Dell'Ariccia, G. (1999), Exchange Rate Fluctuations and Trade Flows: Evidence from the European Union, IMF Staff Papers, 46, pp. 315-334.

Dixit, Avinash (1989a), Hysteresis, Import Penetration, and Exchange Rate Pass-Through, The Quarterly Journal of Economics, 104, pp. 205-228.

Dixit, Avinash (1989b), Entry and Exit Decisions under Uncertainty, The Journal of Political Economy, 97, pp. 620-38.

Dixit, A. and R. S. Pindyck (1994), Investment under Uncertainty, Princeton, NJ: Princeton University Press.

Girma, S., Greenaway, D. and Kneller, R. (2004), Does Exporting Lead to Better Performance? A Microeconometric Analysis of Matched Firms, Review of International Economics, 12, pp. 855-866.

Greene (2003), Econometric Analysis, fifth edition, Prentice-Hall.

Greenaway, D. and Kneller, R (2007a), Firm Heterogencity, Exporting and Foreign Direct Investment, Economic Journal, 117, F134-F161.

Greenaway, D. and Kneller, R. (2007b), Industry Differences in the Effect of Export Market Entry: Learning by Exporting?, Review of World Economics, 143, pp. 416432.

Greenaway, D., Kneller, R. and Zhang, X (2007), Exchange Rates and Exports: Evidence from Manufacturing Firms in the UK, GEP Research Paper 07/13, Leverhulme Centre for Research on Globalisation and Economic Policy, University of Nottingham.

Heckman, James J. (1979), Sample Selection Bias as a Specification Error, Econometrica, 47, pp. 153-61. 
Henley, A., A. Carruth and A. Dickerson (2003), Industry-Wide versus Firm-Specific Uncertainty and Investment: British Company Panel Data Evidence, Economics Letters, 78(1), pp. 87-92.

IMF (1984), The Exchange Rate System: Lessons of the Past and Options for the Future, IMF Occasional Paper No. 30 (Washington: IMF).

Karpaty, P. and Kneller, R. (2005), Demonstration or Congestion? Export Spillovers in Sweden, GEP Research Paper 05/44, Leverhulme Centre for Research on Globalisation and Economic Policy, University of Nottingham.

Kneller, Richard and Pisu, Mauro (2005), Industrial Linkages and Export Spillovers from FDI, GEP Research Paper 05/20, Leverhulme Centre for Research on Globalisation and Economic Policy, University of Nottingham.

Krugman, Paul (1989), Exchange Rate Instability, Cambridge, MA: MIT Press.

Kyriazidou, Ekaterini (1997), Estimation of a Panel Data Sample Selection Model, Econometrica, 65(6), pp. 1335-1364.

Kyriazidou, Ekaterini (2001), Estimation of Dynamic Panel Data Sample Selection Models, Review of Economic Studies, 68, pp. 543-572.

McKenzie, Michael D. (1999), The Impact of Exchange Rate Volatility on International Trade Flows, Journal of Economic Surveys, 13, pp. 71-106.

Vella, Francis, and Verbeek, Mamo (1999), Two-Step Estimation of Panel Data Models with Censored Endogenous Variables and Selection Bias, Journal of Econometrics, 90, pp. 239-263. 